\title{
Glurbanization of the Chinese megacity Guangzhou - image-building and city development through entrepreneurial governance
}

\author{
A. L. Bercht \\ Department of Geography, Kiel University, Ludewig-Meyn-Str. 14, 24098 Kiel, Germany \\ Correspondence to: A. L. Bercht (bercht@geographie.uni-kiel.de)
}

Received: 8 September 2012 - Revised: 11 April 2013 - Accepted: 25 May 2013 - Published: 10 July 2013

\begin{abstract}
The continuing integration of the Chinese economy into the globalizing world and increasing intercity competition have had significant and comparatively recent implications for post-socialist urbanization in China. Driven by market-oriented development and globalization, decentralization of economic decisionmaking and downscaling of governance from the central state to local governments and authorities characterize the changing role of the state from urban managerialism to urban entrepreneurialism. Drawing on Jessop's definition of the entrepreneurial city and his concept of glurbanization, this paper aims to identify and analyse different modes of entrepreneurial urban governance based on the example of Guangzhou, a Chinese megacity that has been under intense pressure to revitalize its leading role as an economic, commercial and cultural centre in the Pearl River Delta and the rest of southern China. To face globalization and promote competitiveness, Guangzhou pursues various innovative interscalar entrepreneurial strategies in an active entrepreneurial fashion through adopting an entrepreneurial discourse. This is critically reflected upon within this article.
\end{abstract}

\section{Introduction}

As recently as $35 \mathrm{yr}$ ago, the People's Republic of China was far from integrated in the process of globalization; it remained, in fact, strongly isolated from the world's political arena. Today, however, China is the world's second largest economy - a benefit of the reform and open-door policy that has been implemented since the 1980s. The continuing integration of the Chinese economy into the globalizing world (e.g. enhanced by China's accession to the WTO in 2001) and increasing intercity competition have had significant and comparatively recent implications for postsocialist urbanization in China. Driven by market-oriented development and globalization, decentralization of economic decision-making and downscaling of governance from the central state to local governments and authorities characterize the changing role of the state from urban managerialism to urban entrepreneurialism (cf. Schröder and Waibel, 2012; Shen, 2007). This transition and a strong orientation to a more outward-focussed stance, intended to enhance national and international economic and urban competitive- ness, lead to a growing emergence of entrepreneurial governance at the city level including innovative entrepreneurial strategies, active entrepreneurial fashion and entrepreneurial discourses. These features are bundled into the notion of glurbanization, a theoretical concept developed by Jessop (1998; cf. also Jessop and Sum, 2000) that has only recently been discussed in the context of China studies (cf. Matusitz, 2010a, b; Wu et al., 2007). Glurbanization states that urban transformation through interscalar strategies can increase competitive advantages in comparison with other cities. Drawing on Jessop's definition of the entrepreneurial city and glurbanization, this paper aims to identify, analyse and critically reflect upon different modes of entrepreneurial urban governance based on a literature review and independent field work in Guangzhou, southern China. Applying a qualitative-interpretive research design, extensive site inspections, semi-structured interviews with urban planners from the South China University of Technology and the Sunyat sen University in Guangzhou, as well as 62 problembased interviews (including the method of auto-photography) 
with inhabitants of Shibi Village were carried out from 2007 to $2011^{1}$. Shibi has been intensively transformed by the impacts of the nearby construction of the new Guangzhou South Railway Station.

Guangzhou is a megacity that has been under intense pressure to revitalize its leading role in the Pearl River Delta through effective urban planning and conscious imagebuilding. Guangzhou, the capital city of Guangdong Province and the largest city in southern China with approximately 10 million inhabitants, represents an excellent example of "how the local state builds up an entrepreneurial city through place-based strategic promotion and entrepreneurial image creation under soft budget constrains" (Wu et al., 2007, 206). It is only very lately that scholars have paid attention to the impact of globalization on the urban development of Chinese cities as well as on the relatively new but striking phenomenon of intercity competition in China (cf. Wehrhahn and Bercht, 2008 and the contributions in Logan, 2008; McGee et al., 2007 and Yeh et al., 2006). In contrast to other cities in the world, the scale and speed of the activities of Chinese cities in regard to place-branding and competitivenessbuilding is unmatched and historically unique.

\section{Research context and conceptual background}

\subsection{Chinese frame of reference}

As documented by contemporary academic debate, the study of post-reform Chinese urban development reveals the diversity and rapidity of the underlying processes and makes evident the struggle of finding the most appropriate (theoretical) lens with which to fully capture, understand and explain the patterns of China's (experimental) urban transition (cf. Lin, 2010; Logan and Fainstein, 2008; Ong, 2011; Roy, 2011). Dominant conceptual approaches, such as the political economy of globalization or postcolonial frameworks, generally remain insufficient due to their prevailing emphasis on "global capitalism" (Ong, 2011, 6) or "subaltern agency" (Roy, 2011, 307) and resistance. As also argued by Wu (2007a), in comparison to Western neoliberalization the Chinese alliance between capital and the (local) state is characterized less by "capital-driven civic boosterism" (ibid., 8) than by strategic interventions that flexibly provide or restrain capital as a (reactive) function of current social stability and political legitimacy (e.g. weighing up the social objective of rehousing residents against the profitmaking goal of relocating residents to cheaper accommodation in the context of conflict-ridden housing redevelopment projects; for a deeper discussion see Tian and Wong, (2007)). From a postcolonial and developmental perspective,

\footnotetext{
${ }^{1}$ The data collection in Shibi Village is based on the wider scope of research addressing psychological stress, coping and resilience in the context of urban transformation processes (cf. Bercht and Wehrhahn, 2010, 2011 for greater detail).
}

theories of modernization, dependency/world system, the developmental state or post-socialist transition are often problematic in that they privilege economic structural change but undertheorize explicit state strategies and policies, emphasize determinist world politics but lack a detailed account of local growth dimensions, point out local structures and processes but neglect the role of agents behind a developmental state, or stress the root of socialism but disregard the stage of economic development and the state's position in the world system (cf. White et al., 2008 and Logan and Fainstein, 2008 for more sustained reflection on these perspectives).

Taking these considerations into account, a hybrid and process-oriented approach, in accordance with White et al. (2008) and Wu (2007a), is thus applied within this paper, placing state action in context and illuminating aspects of urban change through the prism of the developmental state and urban entrepreneurialism. In contrast to Western capitalism, represented by business associations (e.g. chamber of commerce) or unions of private actors and civic boosterism, the Chinese state (central and local) continues to exercise strong state control in the processes of development and regulation, although the implementation of policy instruments is rather driven by consideration of locally based economic competitiveness and entrepreneurial commodifications of place as a space commodity (Wu et al., 2007).

There has been a wide range of literature on urban entrepreneurialism published since Harvey's (1989) essay on urban governance in late capitalism. Many cities worldwide face the pressure of consolidating competitiveness in the course of globalization. The response, however, varies in accordance with the composition of regimes (cf. Wu et al., 2007). Compared to Western countries, China is still an authoritarian regime and the influence of globalization on the locality is mediated by the central government at various levels; foreign investment, for instance, has to be embedded into local politics. The state still manages issues of significant national interest, such as political and social stability, socio-economic strategies or key scientific research and infrastructure projects. Gradual downscaling of governance from the central state to localities, i.e. municipal and urban district governments, thus does not imply a relaxation of state control (a more detailed overview is given by Guthrie, 2009). Unlike most countries in Europe or North America where key actors include private developers, landowners, non-government organizations, elected politicians or chambers of commerce, China's (urban) governance is widely marked by strong party-state leadership, political elitism and local corporatism. In addition, control is exercised over the up and coming multiplayer arena with its multifaceted interrelations between localities and non-state actors such as overseas and domestic investors, planning bureaus or architects (the aspect of multi-level governance in Guangzhou is detailed by Schröder and Waibel, 2012). 
It is against this background that, within the (dialectic) global-local interplay, globalization in China is basically indigenously generated and locally initiated (e.g. devolution of fiscal and administrative powers to local levels, privatization of state housing and state-owned enterprises) and therefore does not represent a simple homogeneous process where the global overcomes the local. It is necessary to deconstruct the concept of globalization from a Chinese angle and to distinguish between internationalization and westernization (McGee et al., 2007). "Local cultures incorporate global symbols but in ways specific to the local context", argue Sun and Chen $(2007,286)$. In line with this argument, $\mathrm{Wu}(2007 \mathrm{a}, 7)$ points out that globalization needs to be seen as a possibility, but that the mode of turning this possibility into reality is shaped by local politics and conditions. For instance the "global" production of Starbucks grasped the Chinese taste for coffee and introduced red bean and green tea frappuccinos. The concept of glurbanization, which is further explained below, refers to the interplay of globalization, urbanization and interurban competitiveness through interscalar entrepreneurial strategies and is thus also relevant to contemporary Chinese cities that are reconceptualized in a global context. The conceptual approaches of glurbanization and the entrepreneurial city are intertwined and ought to be applicable to the Chinese case because they are defined in essentially functional terms, relating to any activities on a wide range of scales and to various actors that promote urban competitiveness. However, the underlying processes and the specific interplay of these variables need to be integrated into the process of Chinese post-socialist transition and into the legacies of state socialism (e.g. lack of urban political autonomy and broad public participation and the influence of Confucianism in which national/community interests, collectivism and social harmony usually override individual rights and self-fulfilment). It is thus less a question of "what" than a matter of "how".

\subsection{Entrepreneurial city and interscalar strategies}

Jessop and Sum (2000, 2289ff.) propose three defining criteria to distinguish the entrepreneurial city from nonentrepreneurial urban regimes. They argue that an entrepreneurial city (a) pursues innovative strategies (aiming to maintain or enhance its economic competitiveness with other cities and regions) in a (b) active entrepreneurial fashion through (c) adapting an entrepreneurial discourse by narrating and marketing the city as entrepreneurial as well as by promoting entrepreneurial images. The first criterion comprises firstly, the introduction of new types of urban place or space for instance for producing, working or consuming (e.g. technopoles, intelligent cities); secondly, new methods of space and place production to create location-specific advantages (e.g. cybernetic infrastructure); thirdly, the opening of new markets to enhance the quality of life for residents or visitors (e.g. sports and entertainment facilities); fourthly, the acquisition of new sources of supply (e.g. inward investment); and fifthly, the redefinition of the urban hierarchy (e.g. development of a global city position, regional gateways, hubs). Entrepreneurial fashion, the second criterion, additionally emphasizes that the strategies need to be reflexive and explicitly formulated to clearly define the interests of the city and to establish the city as a meaningful entity, while the aspect of entrepreneurial discourse, the third feature, directs attention to the city's self-identity and the articulation of various economic, political and socio-cultural narratives. Following the authors' concept, innovative strategies that are adopted by entrepreneurial cities are predominately linked to three possible and different (by no means mutually exclusive) kinds of interscalar articulation. Interscaling implies developing cross-border processes through multiple localities such as neighbourhoods, municipalities, regions and urban zones, each being at a different (territorial) scale (cf. also Lin, 2010; Matusitz, 2010b). The first kind of interscalar strategies reflects the construction of horizontal linkages on the same scale generally due to shared territorial identities (e.g. translocal alliances). Second, vertical linkages involve promoting economic development by exploiting growth dynamics either from the local through the regional and the national to the global or vice versa (e.g. foreign direct investment). The third option is to build transversal linkages that bypass one or more immediately neighbouring scale(s) to enhance closer integration with developments on various other scales (e.g. special economic zone, free ports). Due to the decentralization of state power aiming to increase the efficiency of local economic growth, different localities are thus able to stimulate and develop intercity and global competitive advantages by drawing on interscalar entrepreneurial strategies and rescaling processes. Particularly in China, the adoption of these interscalar strategies represents a new response to the growing variability and flexibility of local governance processes (cf. Wu et al., 2007). In consequence, local governments have transformed from being passive regulators in the previous planned economy to become entrepreneurial agents that initiate and promote city development for local interests.

\subsection{Glurbanization}

Jessop's $(1998,2002)$ concept of glurbanization - the term "glurbanization" is a coinage of the words "global" and "urbanization" - emerged from the fact that cities are increasingly exposed to regional and global competition. The concept centres on the relationship between globalization and urbanization and constitutes a phase beyond the comparatively broad and overarching construct of globalization which generally refers to greater global interconnectedness (also among cities) and the worldwide diffusion of practices (cf. Matusitz, 2010a). Many cities are driven by the process of globalization - a fact that is recognized by the concept of glurbanization. However, its key focus is on the profound changes in urban reconfigurations of these cities within novel 
forms of interurban competition. As Matusitz (2010a, 6) puts it, "since many cities are going global, it is the role of glurbanization theorists to develop a model that helps understand how cities can be made more capable of competing globally". Within this context, Jessop and Sum (2000) distinguish urban from firm-level strategies within the more general concept of "glocalisation" (see Brenner, 1999 and Swyngedouw, 1997 in greater detail). The authors' premise is that glocalisation is most applicable at the level of mobile firms and firm- or sector-based strategies and describes "how global firms seek to exploit local differences to enhance their global operations" (ibid., 2295) by developing new forms of spatial division of labour between different localities. Glurbanization instead, as argued by Jessop and Sum (2000), is pursued by cities to promote their place-based competitive advantages through interscalar strategies in order to acquire certain types of mobile capital and/or fix local capital in place. Against this background, glurbalization - embodying the above mentioned three (analytical) key elements of entrepreneurial strategies, entrepreneurial fashion and entrepreneurial discourse - is hence considered to be a useful concept for exploring new modes of urban governance and the emerging strategies of contemporary entrepreneurial cities worldwide as well as in post-socialist China (cf. Matusitz, 2010b; Wu et al., 2007).

\section{The Guangzhou megacity}

\subsection{Regional and national challenge}

Founded in $214 \mathrm{BC}$, Guangzhou is one of the oldest cities in southern China with a long history of more than $2100 \mathrm{yr}$. It used to be the largest port city in China, known as the "Southern Gate of China", which led to the development of a booming industry, to national and international pre-eminence and a prosperous city community of over one million inhabitants by the year 1840 (cf. Xu and Yeh, 2003). However, Guangzhou's status as a trade and commercial hub and its monopoly in foreign trade were (gradually) weakened after 1840 due to colonial impacts and the subsequent communist takeover. The British victory in the First Opium War resulted in the Treaty of Nanjing that designated, apart from Guangzhou, the four cities of Xiamen, Fuzhou, Ningbo and Shanghai as free-ports, and thus strengthened trade competition for Guangzhou. Finally, the communist party leadership from 1949 to 1978 led to new ideological reorientations and a collectivised economy with free trade and marketization being abolished (see Huang et al., 2010; Xu and Yeh, 2003 for a deeper insight into Guangzhou's history). The major breakthrough for Guangzhou's repositioning as a regional hub was based on the reform and open-door policy introduced in 1979 and the declaration in 1984 that made it one of the seaport cities that were to open their doors to the world market. Since then Guangzhou has experienced far-reaching transformations of great socioeconomic and political signif- icance and rapid urbanization in terms of urban expansion, in-migration processes, land-use change, inner-city renewal, and urban restructuring (cf. also Altrock, 2009). Since the late 1990s, the Guangzhou government has adopted various pro-growth strategies to counter the intense pressure of urban development, to revitalize, firstly, its former role as a commercial, economic and cultural centre and trading port and, secondly, its image as the "Southern Gate of China", to strengthen its attractiveness to investment, and additionally to promote its competitiveness with Peking and Shanghai as well as other cities in the Pearl River Delta, where probably the most intensive intercity competition can be found (cf. Wu et al., 2007). In particular, the return to mainland China of the sovereignty of Hong Kong in 1997 and of Macao in 1999, the rapid development of the nearby cities Shenzhen, Dongguan and Foshan into competitive economic and technological centres as well as Guangzhou's limited land resources for extensive urban development (e.g. restrictions due to the Baiyun Mountain in the north, the administrative boundary with Foshan in the west and high building density in the old town area) have severely challenged Guangzhou.

According to Xu and Yeh (2005), the concept of "competitiveness" in a Chinese context particularly accentuates the need to attract (foreign) capital, enhance economic activities and therefore develop a more business-friendly environment. A widely cited definition by the China Academy of Social Science (CASS) refers to city competitiveness in China as: "The relative ability of a city in comparison with other cities to attract, compete for, sustain, control, and utilize [capital] resources, and the ability to grab and control markets in order to create value for the city and provide [prosperity] to its residents" (Ni, 2001, 1; quoted in Xu and Yeh, 2005, 286). Bearing this definition in mind, the following sections analyse and reflect upon the entrepreneurial strategies, fashion and discourses promoted by the Guangzhou government to enhance competitiveness with other localities in terms of prestige, status and capital.

\subsection{Image-building and city development through entrepreneurial governance}

In the context of the reconsolidation of local power, the nationwide implementation of the City Planning Act (approved by the People's Congress in 1989) authorized municipal governments to prepare urban plans, to define detailed regulations and to select planning and design institutes in accordance with their own visions (cf. Wu and Zhang, 2007). However, the superordinate urbanization policy as a "locomotive of economic growth" (McGee et al., 2007, 210) has been developed at the national level and has been explicitly pushed forward since the Tenth National Five Year Plan (2001-05). The most recent Twelfth Five Year Plan (2011-15) continues to advocate urbanization but also particularly promotes social equality, consumption over investment and exports, and environment protection, and commits 
to transforming coastal regions from being the world factories towards becoming hubs of research and development. The overarching Five Year plans essentially guide city politics and reorientations in local city planning, as becomes evident through the examples discussed in the following.

Until 2000 the Guangzhou government formulated economic strategies within the statutory instrument of the master plan. Driven by the increasing need to capture mobile resources, in 1998 the government initiated a three-step urban development strategy of "minor change in a year, medium change in three, and major change in 2010" (cf. Xu and Yeh, 2003, 368), intended to promote "greenness, amenity and attractiveness" (ibid.). Since 2000, however, the instrument of the more general and rigid master plan has been complemented by the more detailed (non-compulsory) "Guangzhou Urban Development Concept Plan" (abbreviated to "strategic plan") intended to deepen guidance concerning the direction of urban growth and to further specify competitive strategies. This shift is based on the master plan's lack of spatial components, detailed planning standards, future scenarios, elaborated comparisons of the city's advantages and disadvantages, and flexibility because, in contrast to the strategic plan, the Guangzhou master plan requires (time-consuming) approval from the higher level State Council (cf. Wu, 2007b; $\mathrm{Wu}$ and Zhang, 2007). The master plan is still compulsory but is concretized by the more flexible and visionary concept plan that strengthens and integrates strategic formulation, spatial planning, and city marketing into one model. Five prestigious planning and design institutes, located in Guangzhou, participated in the elaboration process of the concept plan. The city government did not provide specific orders for the format and standard of the plan, apart from the enhancement of competitiveness so as to regain the city's pre-eminence in the Pearl River Delta and the rest of southern China. On the basis of the teams' submitted bid and within a deadline of three months, the Guangzhou City Planning Bureau consolidated the proposals and prepared the strategic plan that was (solely) approved by the municipal government in 2000 (cf. Wu, 2007b). This vertical downscaling of planning decision-making from the State Council to the Guangzhou government and from the government via the Guangzhou City Planning Bureau to (skilled) planning and design institutes with planning expertise stimulates the city's development aspirations and reduces the ability of the central state to influence the outcomes and processes of the city's entrepreneurial activities and place promotion.

This planning procedure makes evident Guangzhou's increasingly active and reflexive entrepreneurial fashion that is characterized by the formulation of real and not "as if" strategies (Jessop and Sum, 2000, 2289) through a more precise entrepreneurial discourse. The concept plan explicitly promotes a polycentric form of future growth and a shift of the city's core area from the old town along the city development axes to the eastern and southern part of Guangzhou, aiming to move closer to the economic heartland of the
Pearl River Delta and strengthen its business and trade role. Due to limited land resources (cf. Sect. 3.1), the new spatial strategy is, as outlined in $\mathrm{Wu}(2007 \mathrm{~b}, 385)$, summarized as "constraining the north, adjusting the west, expanding the south and relocating the east". In line with these objectives, Guangzhou initiated a number of strategic physical and institutional interscalar changes to enable the production of new entrepreneurial space. One of two significant examples is the horizontal rescaling of the city's administrative boundary by annexing the county-level cities Huadu and Panyu as two new urban districts in 2000 (cf. Shen, 2007). This territorial expansion of the city was combined with a tactical concern to gain control of the new Baiyun International Airport being constructed in Huadu (and opened in 2003) and the port facilities in Panyu as well as to locate a new CBD in the middle of Panyu (interviews with urban planners in 2009). The second example refers to the vertical upscaling of the state-designated Guangzhou Economic and Technological Development Zone (ETDZ) as well as the Nansha Development Zone (NDZ) by turning them into urban districts in 2005. This creation of urban space allows more localized urban governance by increasing the supervision and management of the development zones that play a key role for (vertically) attracting foreign capital, promoting export and building high-tech industries (cf. Wu et al., 2007, 141ff.). Inside the new space, the local government is entitled to implement new policies such as tax exemption or fee relief. These innovative entrepreneurial strategies additionally reflect, in accordance with Jessop and Sum's (2000) glurbanization concept, the finding of new sources of supply (particularly regarding inward investment) to boost economic performance.

Against this background and in terms of redefining urban hierarchies, priority is given to the enhancement of four (transversal) hub functions of the city: an "aviation hub" based on the new airport; a "shipping hub" based on the Nansha Deep Water Port; an "information hub" led by the Convention and Exhibition Center, Bio-Island, University Town and the currently planned start-up area of the Guangzhou Knowledge City to attract talent and skilled manpower and knowledge-based industries; and, fourthly, a "railway passenger hub", being realized through the construction of the new Guangzhou South Railway Station in Shibi Village. Since 2004, when implementation of the latter project began, Shibi's inhabitants have had to face profound impacts on their living conditions. Massive land expropriation, uncertainty about compensation fees and forced resettlement, and change of employment and income structures severely influence the quality of local human-environment transactions (interviews 2007 to 2011; cf. Bercht and Wehrhahn, 2010, 2011 for greater detail). The conversion of the village's collectively owned agricultural land into urban construction land illustrates a comparatively new strategy of urban space production by vertically upscaling the land management structure. A $30 \mathrm{yr}$-old villager expressed her fear about the future within the frame of auto-photography. She 


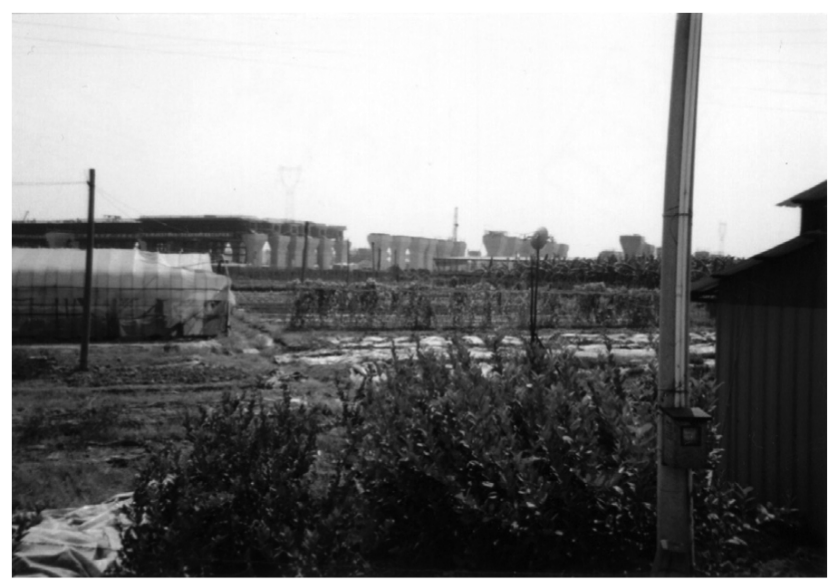

Figure 1. Conversion of agricultural land into developed sites for the Guangzhou South Railway Station project in Shibi Village in 2008 (Photo: Taken by an interviewee within the frame of autophotography investigation).

took a photograph of parts of the former agricultural area (Fig. 1) that is now mostly being used for the railway tracks.

"A lot of villagers have lost their basic source of income and haven't received enough compensation payments from the village committee. How shall they make a living if not from farming?" (interview 2008). The government has not provided any information on the extent to which the residential area might be affected by the railway construction site, which evokes agonising uncertainty (interviews 2007 to 2011). The first part of the railway station was opened in January 2010; the whole station, consisting of 28 railway tracks, is scheduled to open in 2013. The government's declared aim is to increase passenger handling capacity and thus to strengthen Guangzhou's position as a regional hub city that can compete with Hong Kong, Wuhan, Beijing and Shanghai. Upon completion, the South Railway Station will be the largest and most modern passenger railway station in Asia. According to Zhang Guangning, the former Mayor of Guangzhou (2003 to 2010), the area around the railway station will be integrated into southern Guangzhou's centre for commerce, trade and tourism and will "become the most important functional extension of the city's central district" (Guangzhou Municipality, 2010).

The predominant entrepreneurial discourse of Guangzhou narrates the city as a "globalizing regional center and scenic ecological city" (Wu and Zhang, 2007, 730) based on key infrastructure projects, sustainable transport systems and the development of green space and artificial landscapes presenting images of a flourishing city. Image enhancement can be seen as part of the new methods of the (horizontal) space production and the opening of new markets. These include large transportation projects (e.g. new metro masstransit, flyovers), fancy face-lifting projects (e.g. Guangzhou TV-Tower, CITIC Plaza, Grant Opera House), new specta-

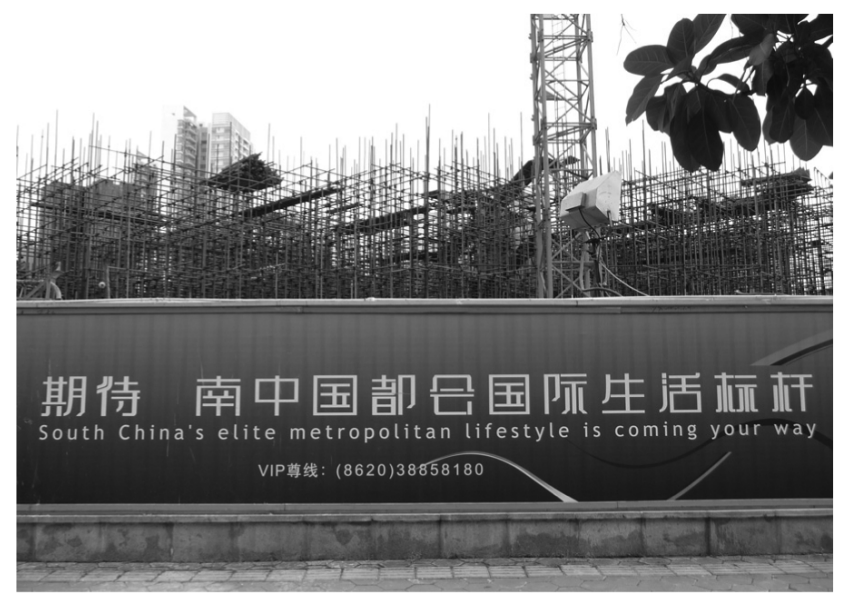

Figure 2. Poster campaign 2011 in front of a residential construction site to narrate Guangzhou as a world-class city with international living standards (Source: author's photo).

cles (e.g. urban nightscape lighting projects along the Pearl River promenade to enhance night-life tourism), the adoption of Western architectural styles (e.g. modern skyscrapers with complex glass facades), the establishment of Western retailers (e.g. IKEA, Starbucks), luxury (gated) residential areas (cf. Breitung, 2012) that make "South China's elite metropolitan lifestyle ... coming your way" (Fig. 2) and the hosting of international mega-events such as the China Import and Export Canton Fair (twice a year) or the 16th Asian Games in 2010 that are "shared by the world" (Fig. 3). The Asian Games represent a crucial step towards establishing an extroverted and globally interacted city image and hence to building up an international identity. In the slogan of the Games - "Thrilling Games, Harmonious Asia" - the Confucian idea of harmony symbolically represents traditional values and advocates "a world where different civilizations and cultures exist in harmonious juxtaposition" (Zhu et al., 2011, 6). Moreover, media is embedded into the reshaping of the city's image. For instance, two TV series in the style of soap operas were produced about pioneering and experimental enterprises in Guangzhou, using the image of the CBD Zhujiang New Town as a major backdrop (cf. Wang, 2005). Through the use of these post-modern features, Guangzhou's far-reaching discourse symbolizes modernity, civilization and prosperity, creates a business-friendly environment and thus assures that a familiar local lifestyle is available to external investors and expatriates.

Alongside these aspirations, environmental protection and sustainable development have a growing stake in Guangzhou's entrepreneurial innovative strategies. Awareness is increasing that advocating and achieving ecological and socially harmonious settings is gaining importance, especially in terms of attracting investors and a skilled labour force, and conforming to modern values and expectations of life quality (interviews with urban planners in 2009). 


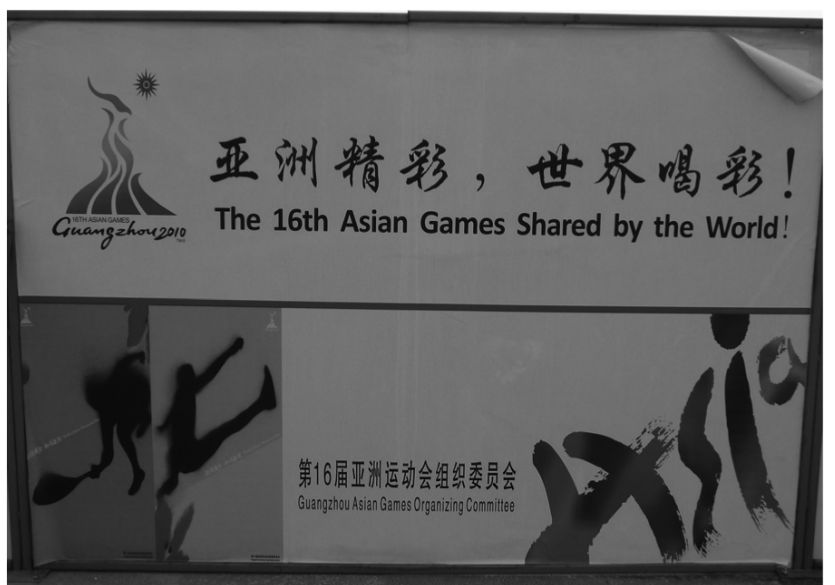

Figure 3. Poster campaign 2010 to visualize Guangzhou's transversal integration into the global world (Source: author's photo).

The implementation of the $22.5 \mathrm{~km}$ Guangzhou bus rapid transit (BRT) corridor, opened in February 2010, represents an illustrative example of following this strategy and applying a new method of space and place production. It is the first BRT system in China and, after Bogota's, the second largest worldwide. The Guangzhou BRT, with one bus every ten seconds into the city in the morning rush hour and 350 buses moving up to 29000 people every hour, integrates with bike lanes, public bike share and metro stations. It benefits the urban poor, cuts traffic congestion on one of the city's busiest roads (Zhongshan Avenue), and reduces Guangzhou's $\mathrm{CO}_{2}$ emissions by 86000 tonnes annually (ITDP, 2011; UN, 2013). In 2011, the BRT won (against, for instance, Lima/Peru and Nantes/France) the Sustainable Transport Prize granted by the United States Institute for Transportation and Development Policy, a non-profit organization, and in 2012 was selected by the United Nations Climate Change Programme as a Lighthouse Activity as it is "a model for the affordable, low-carbon high-volume public transit desperately needed by fast-growing cities in the developing world" (UN, 2013). Not only these awards but also favourable international press (e.g. report on the Guangzhou BRT in the New York Times, 2010) sanitize - on an international arena and using an entrepreneurial discourse - the image of Guangzhou, portraying it as a liveable ecological city, promoting not only economic growth but also the improvement of local living standards. In contrast to the abovementioned Guangzhou South Railway Station project, which displays a rather symbolic and prestigious value, the BRT system reflects the government's serious efforts to enhance sustainable city development.

In summary, the cited examples relating to entrepreneurial interscalar strategies, fashion and discourse illustrate that state power is increasingly being scaled down, while urban power is scaled up. The results have been a new style of urban governance and multifaceted urban restructuring pro- cesses. Guangzhou is seen as a product that needs to be marketed whereby prominence is still primarily given - and this is consistent with the quotation on the Chinese understanding of competitiveness mentioned above - to economic efficiency and the enhancement of greater economic autonomy. As appropriately stated by Matusitz (2010a, 7; emphasis in original), "glurbanization encapsulates the qualitatively new forms of governance both in the urban and through the urban". Against this overall background, Guangzhou can be considered as a reflexive and glurbalized city, linking globalization and urbanization in an entrepreneurial manner and ensuring the integration into global networks. In this sense however, globalization does not represent forces that simply drop down a scalar ladder of global-local. The example of Guangzhou as the host city for the Asian Games demonstrates this point. The city image is not solely shaped by global forces. The existence of traditional Chinese cultural styles makes evident that global forces are greatly mediated by local influences. The global and the local thus dialectically constitute a specific Chinese global-local-nexus.

\section{Critical reflections and conclusions}

Since the reforms of the 1980s, the entrepreneurial strategies of harnessing large key projects and mega-events as well as projecting new and dynamic city images as a means of enhancing economic growth and competitiveness have become extremely popular in Chinese cities, in particular in Guangzhou, a city that is desperate to raise its status in the Pearl River Delta and the rest of southern China. With large investments in road construction and transport facilities, mobility has been significantly improved and, as revealed by opinion polls (cf. Wu et al., 2007, 222), benefits the citizens of Guangzhou. In 2001 the city was awarded the title of international "garden city" and in 2005 Guangzhou received the "United Nations' Best Improvement of Human Settlement" Award for successfully upgrading the resident's living conditions (cf. ibid.; Xu and Yeh, 2003, 368).

The strategic plan primarily aims to promote an atmosphere of pursuing economic growth and thus still prioritizes capital investors and economic efficiency over residents and social welfare (cf. Wu et al., 2007) or, as Harvey (1989) suggests, amounts to a subsidy for the affluent at the expense of the poor. "I only build for the rich", openly claimed Ren Zhiqiang in 2006 (cf. Wu et al., 2007, 12), one of China's best known developers. His statement reflects the general attitude toward entrepreneurial priorities, namely that money cannot be made by building for the poor. Instead, the implementation of large key projects, such as the Grand Opera House or the South Railway Station, renders achievement more impressive and easily visualized than unimpressive social housing and "intangible" social welfare (cf. also Xu and Yeh, 2005, 301). Adding to the rapid competitiveness building, government officials, particularly mayors who face 
enormous pressure to successfully fulfil expectations, are additionally motivated to develop large projects for their own career advancement. This can lead to overspending and unwise investment. For example, one main reason for constructing the South Railway Station was to reduce the travel time (especially for work commuters) between Guangzhou and Hong Kong from $100 \mathrm{~min}$ (before the year 2011) to $50 \mathrm{~min}$ by implementing a rail network suitable for high-speed intercity express trains. However, to reach the central business district from the South Railway Station, travellers face an 18stop metro ride which takes about $45 \mathrm{~min}$. In the end, travel time has not been significantly shortened.

The concept plan is, as addressed above, prepared within a very short period of time, thus making solid research in terms of long-term efficiency and feasibility impossible. Rather, the plan tends to propose strategic actions that are to be realized hastily and neglects the profound details of implementation. In consequence, as argued by $\mathrm{Wu}$ and Zhang (2007, 735), "the strategic plan is not stable because new political leaders often wish to demonstrate their achievement in office". Against this background, large projects may lead to controversies and social conflicts as a result of (a) spending scarce public-sector resources on fancy projects instead of on welfare-related needs (e.g. education, social housing), (b) relocating inhabitants (e.g. in consequence of the Guangzhou University Town project), (c) displacing land-use functions and (d) not providing sufficient information to affected inhabitants regarding their settlement's future development (e.g. in relation to the implementation of the South Railway Station). For instance, claiming lack of funding, the Guangzhou government ignored the essential rebuilding of deprived schools in the inner city but at the same time invested in the construction of the Guangzhou Opera House to bring new cultural significance to the city (cf. Wu et al., 2007). It can be assumed that this diversion of capital has a negative longterm impact upon the disadvantaged in the city. According to $\mathrm{Xu}$ and Yeh (2005), entrepreneurial governance is primarily associated with two elite groups in Chinese cities. Firstly, with the local government officials who pursue the expansion of economic growth, strive to demonstrate gains through quick and visible actions, and wish to create opportunities for their own career advancement. Secondly, to investors that strive for the goal at making profit within short planning periods. To realize entrepreneurial strategies on a large scale and at rapid speed, the involvement of the public is considered as less efficient in achieving economic targets. The strategic plan basically reflects the visions of local leaders and is not formulated through public participation or on the wider basis of public debate. However, it has to be pointed out that the example of the BRT system for sustainable development and urban regeneration reveals that innovative entrepreneurial strategies additionally go beyond a sole focus on direct economic efficiency. Social needs are met and (international) recognition is won, creating a positive and image-improving entrepreneurial discourse that aims to make the city more liveable and at the same time competitive and attractive for investors and talents.

The outcomes of Guangzhou's glurbanization process span the range from success to malfunction and can thus be considered as twofold. On the one hand, the concept plan enables flexible and creative urban restructuring and the residents at large (may) benefit from the new transport, entertainment and shopping facilities and from the general increase in living standards. On the other hand, though, the innovative entrepreneurial strategies, fashion and discourse do not represent the unified interests of the city - "not everyone gains from enhanced local prosperity" (Wu et al., 2007, 229). The entrepreneurialism results in debt-burdened local finance, misuse of public resources and social conflicts. At this stage, it is difficult to foresee the sustainable effect and long-term success of Guangzhou's various entrepreneurial strategies. However, the ongoing unbalance between public needs and official interests as well as the wide neglect of investment in non-prestige projects (e.g. in school equipment or housing for migrant workers and relocated residents) encourages the assumption that existing problems may worsen and that new problems (e.g. severe lack of finance, increase of public resistance) may emerge and retard the city.

The case study of Guangzhou cannot be taken as being representative of all Chinese cities. Nevertheless, the analysis of glurbanization processes in Guangzhou might generate new and significant insights into the dynamics of a postsocialist city that is integrating itself into global networks and competing with other cities for status and capital.

Acknowledgements. The research investigations presented in this paper were funded by the German Research Foundation (DFG) within the Priority Programme 1233 "Megacities - Megachallenge: Informal Dynamics of Global Change". The support of the DFG, my colleagues, my Chinese field assistants as well as the interviewees' willingness to participate in the study are thankfully appreciated. Furthermore I kindly acknowledge the constructive and valuable comments of two anonymous reviewers on an earlier draft of this paper.

Edited by: O. Söderström

Reviewed by: two anonymous referees

\section{References}

Altrock, U.: Stadtumbau im Perlflussdelta: Zwischen Quartiersentwicklung und Kommodifizierung, in: Megacities und Stadterneuerung. Jahrbuch Stadterneuerung 2009, edited by: Altrock, U., Kunze, R., Pahl-Weber, E., Petz, v. U., and Schubert, D., Universitätsverlag der TU Berlin, Berlin, 141-161, 2009.

Bercht, A. L. and Wehrhahn, R.: A psychological-geographical approach to vulnerability: the example of a Chinese urban development project from the perspective of the transactional stress model, Environ. Plann. A, 42, 1705-1722, 2010. 
Bercht, A. L. and Wehrhahn, R.: Urban restructuring processes in Guangzhou/China - the significance of emotion-focussed coping, Geogr. Z., 99, 50-64, 2011.

Breitung, W.: Enclave urbanism in China: attitudes towards gated communities in Guangzhou, Urban Geogr., 33, 278-294, 2012.

Brenner, N.: Globalisation as reterritorialisation: the re-scaling of urban governance in the European Union, Urban Stud., 36, 431451, 1999.

Guangzhou Municipality: South Railway Station scheduled for opening on 30 January, Guangzhou, http://gz.gov.cn/vfs/subsite/ JGIN7QPB-AZE4-2MTO-EA6G-R281E8V2SFJH/content/ content_visitor.jsp?contentId=737201\&catId=5944, last access: 31 August 2010.

Guthrie, D.: China and globalization. The social, economic and political transformation of Chinese society, Revised Edition, Routledge, New York, 2009.

Harvey, D.: From managerialism to entrepreneurialism: the transformation of urban governance in late capitalism, Geogr. Ann. B, 71, 3-17, 1989.

Huang, L., Li, B., and Sun, Y.: Study on history of modern urban planning of Guangzhou, China City Planning Review, 19, 60-72, 2010.

ITDP (Institute for Transportation and Development Policy): Guangzhou BRT reduces $\mathrm{CO}_{2}$ emissions by 86,000 tonnes annually, http://www.itdp.org/news/ (last access: 7 March 2013), 2011.

Jessop, B.: The narrative of enterprise and the enterprise of narrative: place marketing and the entrepreneurial city, in: The entrepreneurial city. Geographies of politics, regime and representation, edited by: Hall, T. and Hubbard, P., John Wiley and Sons, New York, 77-99, 1998.

Jessop, B.: The future of the capitalist state, Polity Press, Cambridge, 2002.

Jessop, B. and Sum, N. L.: An entrepreneurial city in action: Hong Kong's emerging strategies in and for (inter)urban competition, Urban Stud., 37, 2287-2313, 2000.

Lin, G. C. S.: Scaling-up regional development in globalizing China: local capital accumulation, land-centred politics, and reproduction of space, in: Globalizing regional development in East Asia. Production networks, clusters, and entrepreneurship, edited by: Yeung, H. W. C., Routledge, London, 115-132, 2010.

Logan, J. R. (Ed.): Urban China in transition, Blackwell Publishing Ltd, Oxford, 2008.

Logan, J. R. and Fainstein, S. S.: Introduction: Urban China in comparative perspective, in: Urban China in transition, edited by: Logan, J. R., Blackwell Publishing Ltd, Oxford, 1-23, 2008.

Matusitz, J.: Glurbanization theory: an analysis of global cities, International Review of Sociology - Revue Internationale de Sociologie, 20, 1-14, 2010a.

Matusitz, J.: Collapsing the global and the local through interscalar strategies: a glurbanization perspective, Planning Theory, 9, 627, 2010b.

McGee, T. G., Lin, G. C. S., Marton, A. M., Wang, M. Y. L., and Wu, J.: China's Urban Space. Development under market socialism, Routledge, New York, 2007.

New York Times: Chinese cities find bus-only lanes an alternative to cars and subways, http://www.nytimes.com/cwire/2010/07/16/ 16climatewire-chinese-cities-find-bus-only-lanes-an-altern- 10489. html?pagewanted=all (last access: 7 March 2013), 2010.
Ni, P.: Tisheng zhongguo chengshi jingzheng li de gongxuan lilun yu zuquan zhanlue (A theory and clustering strategy to promote Chinese cities' competitiveness), http://www.macrochina. com.cn (last access: 28 May 2004), 2001.

Ong, A.: Worlding cities, or the art of being global, in: Worlding cities: Asian experiments and the art of being global, edited by: Roy, A. and Ong, A., Blackwell Publishing Ltd, Oxfort, 1-26, 2011.

Roy, A.: Postcolonial urbanism: Speed, hysteria, mass dreams, in: Worlding cities: Asian experiments and the art of being global, edited by: Roy, A. and Ong, A., Blackwell Publishing Ltd, Oxfort, 307-335, 2011.

Schröder, U. and Waibel, M.: Urban governance and informality in China's Pearl River Delta. Investigating economic restructuring in Guangzhou, Z. Wirtsch., 56, 97-112, 2012.

Shen, J.: Scale, state and the city: urban transformation in postreform China, Habitat Int., 31, 303-316, 2007.

Sun, J. and Chen, X.: When local meets global. Residential differentiation, global connections and consumption in Shanghai, in: China's emerging cities. The making of new urbanism, edited by: Wu, F., Routledge, New York, 284-302, 2007.

Swyngedouw, E.: Neither global nor local: "glocalisation" and the politics of scale, in: Spaces of globalization: reasserting the power of the local, edited by: Cox, K., The Guilford Press, London, 138-166, 1997.

Tian, Y. Y. and Wong, C.: Large urban redevelopment projects and sociospatial stratification in Shangai, in: China's emerging cities. The making of new urbanism, edited by: Wu, F., Routledge, New York, 210-231, 2007.

United Nations: Guangzhou Bus Rapid Transit system, http: //unfccc.int/secretariat/momentum_for_change/items/7101.php, last access: 7 March 2013.

Wang, N.: Urbanscape as attraction. The case of Guangzhou, in: Seductions of place: geographical perspectives on globalization and touristed landscapes, edited by: Cartier, C. and Lew, A. A., Routledge, New York, 135-147, 2005.

Wehrhahn, R. and Bercht, A. L.: Guangzhou/Perlflussdelta - Konsequenzen der Weltmarktintegration für die mega-urbane Entwicklungsdynamik in China, Geographie und Schule, 30, 1827, 2008.

White, M. J., Wu, F., and Chen, Y. P.: Urbanization, Institutional Change, and Sociospatial Inequality in China, in: Urban China in transition, edited by: Logan, J. R., Blackwell Publishing Ltd, Oxford, 115-139, 2008.

Wu, F.: Beyond gradualism. China's urban revolution and emerging cities, in: China's emerging cities. The making of new urbanism, edited by: Wu, F., Routledge, New York, 3-24, 2007a.

Wu, F.: Re-orientation of the city plan: strategic planning and design competition in China, Geoforum, 38, 379-392, 2007b.

Wu, F. and Zhang, J.: Planning the competitive city-region. The emergence of strategic development plan in China, Urban Aff. Rev., 42, 714-740, 2007.

$\mathrm{Wu}, \mathrm{F}$, $\mathrm{Xu}, \mathrm{J}$. , and Yeh, A. G.-O.: Urban development in postreform China. State, market, and space, Routledge, New York, 2007.

Xu, J. and Yeh, A. G. O.: City profile, Cities, 20, 361-374, 2003.

$\mathrm{Xu}, \mathrm{J}$. and Yeh, A. G. O.: City repositioning and competitiveness building in regional development: new development strategies in Guangzhou, China, Int. J. Urban Regional, 29, 283-308, 2005. 
Yeh, G.-O., Sit, V. F.-S., Shen, G., and Zhou, Y. (Eds.): Developing a competitive Pearl River Delta in South China under one countrytwo systems, Hongkong University Press, Hongkong, 2006.
Zhu, H., Qian, J., and Gao, Y.: Globalization and the production of city image in Guangzhou's metro station advertisements, Cities, 28, 221-229, 2011. 